sential degree, a malady, which, in spite of the rapid advancement of medical science, still bids defiance to all human skill. What is here aimed at, is to place Jersey in its true position among climates of a similar nature, and to draw inferences of practical value, concerning particular morbid actions, which, though sometimes the conseyuences of $p$ hthisis, have, not unfrequently, a separate existence, and admit of a successful treatment. Of this kind is hamoptysis. I believe it to be generally admitted, by modern pathologists, that the latter disease, when simple, is very rarely occasioned by the erosion of a large blood-vessel; and that, in the majority of cases, the hæmorrhage results from an exhalation of blood on some part of the mucous membrane of the respiratory channels. Now, the state of the mucous membrane predisposing to this affection, is certainly not common in this island; a state widely different from that which induces the diseases, known by the general ter'm catarrhal, prevalent under the meteorological influences which characterise this climate.

" From the preceding observations, it may be seen that I consider Jersey entitled to a very high character, among the English climates most suited to invalids labouring under incipient pulmonary consumption, and idiopathic hamoptysis."

\section{POISONING WITH ARSENIC, PER VAGINAM.}

\section{To the Elitor of Tine Lancet.}

SIR :-Regarding the different modes in which arsenic has been administered as a poison, allow me to mention the following very unusual one:-In the "Comment de Rebus," Leipsic, 1793, tom. 35, and in "Metzger," p. 390, we find the story of two women-" Quibus per vaginam oxidum ar. senici marito admotum est. Occubuere ambe; harum una inopinato et perdurante horrore et urente vagina dolore correpta est et post vomitus fere continuos et deliria, elapsis 28 horis ab applicatione veneni, mortua est. Sectio monstravit abdomen uon tumidum, nullas in cute maculas, labia vulva magna paulum tumida et rubra; in vagina, patula flacida pauca grana arsenici crystallini." Permit me to take this opportunity of adding, that I think that the publication of the valuable Lectures of Professor $A$. T. Thomson have considerably advanced our knowledge in medical jurisprudence, a branch which had hitherto been so much neglected. I am Sir, yours, \&c.

MORGaN J.

\section{THE LA NCET.}

London, Saturday, September 16, 1837.

TuE subject of medical education, which we last week noticed as one that was particularly suited for discussion at the present moment, overflows with interest and importance, not only to parents and pupils, but to medical practitioners themselves, who have quitted the closet of study for the field of experience. The road of connection between the quarters of the medical student and the domain of the surgeon is a brief threshold, and the practitioner who thinks that he may cease to regard with anxiety the proceedings in the one, can attach but little interest to the privileges, the profits, and the reputation of the other. He may not be an examiner at the College or the Hall, or live in Lincoln's-Inn-Field or Blackfriars, in such a position as to witness the ceaseless influx of new competitors from the little schools of medicine to the great school of practice. But to suppose for an instant that he can regard with indifference the possibility of his being either ruthlessly trod. den under foot by a crowd, or honourably and effectually assisted in his labours as a physician and a man of science, by colleagues fresh from the halls of science,-this is to suppose the practitioners of England insane, or conceited, or criminally indifferent to an in:measurable extent, where reason, the commonest prudence, and praiseworthy sensibility, should be prominent characteristics of their thoughts and actions. Indeed, were there no other motive to incline them to watch narrowly the condition of medical education, this alone should suftice to induce a minute at: tention to its details, - that the mark on the scale of knowledge which the candidate for rank in the profession is required to reach, determines the number and character of rivals in the arena of practice; for it is past all question that a large amount of scientific attuinments is inconsistent with an excessive

August $31,1837$. 